\title{
ЕТАПИ РОЗВИТКУ ДИСТАНЦІЙНОЇ ОСВІТИ В УКРАЇНІ
}

\author{
У статті розглянуто етапи становлення та розвитку вітчизняної системи дистанційної освіти, яка безупинно \\ розширює сприйняття комплексності світу та формування інформаційного суспільства. \\ Ключові слова: дистаниійна освіта, професійна підготовка, інформачійні технології, підвищення кваліфікації. \\ В статье рассмотрены этапь становления и развития отечественной системь дистанцонного образования, \\ которая беспрерывно расширяет восприятие комплексности мира и формирования информационного общества. \\ Ключевые слова: дистанционное образование, профессиональная подготовка, информационные технологии, повышение \\ квалификации.
}

The article considers formation and development stages of the Ukrainian system of education by correspondence, which continually extends perception of the world complexity and informative society formation.

Key words: education by correspondence, professional training, information technologies, advanced training.

Науково-технічний прогрес, широке запровадження наукових інформаційних технологій потребують значного підвищення якості професійної підготовки кваліфікованих робітників, іï фундаменталізації та гнучкості. Розв’язати цю проблему можна через добре відому в усьому світі систему дистанційного навчання. Це відкрита система навчання, що передбачає активне спілкування між викладачем і студентом за допомогою сучасних технологій та мультимедіа. Така форма навчання дає свободу вибору місця, часу та темпу навчання. Дистанційна освіта розв’язує проблему підвищення кваліфікації тих, хто проживає і працює в регіонах і для кого переїзд до іншого міста пов’язаний з багатьма проблемами.

Мета статmі полягає у визначенні етапів розвитку системи дистанційної освіти в Україні.

Завдання:

- осмислити й проаналізувати теоретичні, практичні та соціальні аспекти дистанційної освіти;

- розглянути основні етапи становлення та розвитку системи дистанційної освіти в Україні.

Розвиток дистанційної освіти в Україні розпочався значно пізніше, ніж у країнах Західної Свропи і здійснювався за умов низького рівня інформатизації українського суспільства, незначної кількості оснащення комп'ютерною технікою шкіл України та відсутності спеціалізованих методик дистанційного навчання. Теоретичні, практичні та соціальні аспекти дистанційної освіти були розроблені в нашій країні недостатньо. Кількість наукових організацій та вищих навчальних закладів України, які б активно розробляли або використовували відповідні курси дистанційного навчання теж була досить незначною [4, с. 41].

У розвитку дистанційної освіти в Україні можна умовно виокремити кілька етапів. Перші кроки до розвитку ДО в Україні було зроблено наприкінці 90-х років. У лютому 1998 р. Верховна Рада прийняла Закон України «Про національну програму інформатизації»[2], у якому сформульовано завдання 3 інформатизації освіти та визначено напрямки їх реалізації. Із моменту прийняття цього закону у системі освіти України відбулися позитивні зміни в галузі інформатизації та освоєння Internet.

Із 1997 р. в Україні систематично проводяться Всеукраїнські конференції «Інтернет-технології в інформаційному просторі держави». У 1998 р. науковці країни провели конференцію в Одесі, на якій відбулося підписання меморандуму про співробітництво між 27 ВНЗ України. Спільною постановою Президії Національної академії наук України і Колегії Міністерства освіти України в 1997 р. створено Асоціацію користувачів телекомунікаційною мережею закладів освіти i науки України 3 координуючим «Центром Європейської інтеграції» у м. Києві, який у подальшому отримав офіційну назву Українська науково-освітня телекомунікаційна мережа «УРАН».

У 2000 р. Міністерство освіти і науки України затвердило «Концепцію розвитку дистанційної освіти в Україні» [3], яка передбачала створення в країні системи освіти, що забезпечує розширення кола споживачів освітніх послуг, реалізацію системи безперервної освіти «протягом всього життя» та індивідуалізацію навчання при масовості освіти. Створення Українського центру дистанційної освіти на основі Національного технічного університету України «Київський політехнічний інститут» дало можливість проводити в Україні курси навчання для викладачів ВН3, розроблювачів дистанційних курсів і укладати договори з ВНЗ про співробітництво 3 метою координації створення системи дистанційної освіти в Україні.

Отже, розвиток дистанційної освіти в Україні пройшов два фундаментальні етапи становлення. Згідно 3 «Концепцією розвитку дистанційної освіти в Україні» від 20 грудня 2000 р. на першому етапі розвитку вітчизняної дистанційної освіти протягом 2001 р. відбулося: створення організаційної структури системи дистанційної освіти; розробка правових основ і стандартів дистанційної освіти; створення матеріально-технічної бази регіональних i локальних центрів дистанційної освіти; створення первинного фонду дистанційних курсів i забезпечення їх експериментального впровадження; розробка засад фінансування системи дистанційної освіти; реалізація пілотних проектів упровадження дистанційної освіти [4, с. 43]. 
На другому етапі розвитку дистанційної освіти в Україні протягом 2002-2003 рр. здійснено: повномасштабне розгортання і впровадження дистанційної освіти як форми навчання, рівноцінної 3 очною, заочною та екстернатом; упровадження системи багатоканального фінансування юридичних і фізичних осіб системи дистанційної освіти; розробка і впровадження системи пільг щодо використання комп'ютерних мереж і телекомунікаційної інфраструктури для складових системи дистанційної освіти (юридичних і фізичних осіб); упровадження системи ліцензування, атестації та акредитації закладів дистанційної освіти; інтеграція системи дистанційної освіти України у світову систему.

Організаційна структура системи дистанційної освіти України зараз включає: Раду з питань моніторингу розвитку дистанційної освіти при Кабінеті Міністрів України; координаційну Раду Міністерства освіти і науки України з питань дистанційної освіти; Український центр дистанційної освіти; регіональні центри дистанційної освіти у містах Харків, Львів, Одеса, Донецьк, Дніпропетровськ, Хмельницький; локальні, центри дистанційної освіти; базові центри дистанційної освіти за напрямками фахової підготовки; науково-методичні комісії за напрямками діяльності системи дистанційної освіти [5, с. 21].

Запровадження дистанційної освіти в систему навчання зумовило значні зміни усієї їі організації. Застосування технологій дистанційного навчання відкрило більш широкі можливості у професійній підготовці, перепідготовці та підвищенні кваліфікації дорослих.

Нині сучасний ринок освіти в Україні пропонує широкі можливості навчатися дистанційно й отримати при цьому спеціальність. Наприклад, у Міжнародному університеті фінансів можна дистанційно отримати знання без відриву від виробництва зі спеціальностей: «Фінанси», «Банківська справа», «Облік і аудит». По закінченні навчання студенти одержують диплом про вищу освіту. Термін навчання $-5,5$ років. Університет тісно співпрацює з Українським центром дистанційного навчання при Національному технічному університеті України «Київський політехнічний інститут». У Центрі вже наразі можна підвищити кваліфікацію з OC Linux Red Hat 6.13 одержанням відповідного сертифіката, пройшовши навчання за курсом «Введення в ОC Linux» [5, с. 26].

Міжнародний центр дистанційної освіти Академії державного управління при Президенті України входить до Навчальної мережі глобального розвитку Світового банку, що об'єднує понад 50 подібних центрів у Європі, Америці, Азії та Африці. Центр має відео-конференц-зал для одно- та двоспрямованого зв'язку та дві Інтернет-аудиторії. Основними напрямами діяльності центру $є$ підготовка магістрів за спеціальністю «Управління суспільним розвитком» за заочно-дистанційною формою навчання на основі сучасних інформаційно-комунікаційних технологій, проведення дистанційних курсів з державного управління, управління проектами, менеджменту, економіки, маркетингу та розвиток дистанційної освіти в Україні [1, с. 77].

В Одеській національній академії зв'язку імені А. С. Попова, де створено Центр дистанційного навчання, широко використовується апробована система дистанційного навчання для перепідготовки та підвищення кваліфікації фахівців у галузі зв'язку. Система адаптована для використання в структурах підприємств «Укртелеком» та «Укрпошта». В Академії функціонують такі дистанційні курси: локальні комп'ютерні мережі, напівпровідникові джерела випромінювання, охорона праці, філософія, хімія, електроматеріали тощо [5, с. 42].

Проект «Українська система дистанційного навчання» (UDL System), у розробленні якого безпосередню участь брали представники Львівського інституту менеджменту, пропонує курси переважно за економічними напрямками: менеджмент, маркетинг, проводить набір на дистанційну форму навчання популярної програми МВА [5, с. 43].

На факультеті перепідготовки фахівців 3 нових напрямів науки, техніки та технологій Київського національного університету будівництва й архітектури проводиться дистанційне навчання за програмою «Менеджмент персоналу й виробничі відносини». Навчальна програма розроблена в межах проекту TEMPUS-TACIS за участю Фернуніверситету міста Хагена (ФРН) і розрахована на тих, хто вже має вищу освіту та бажає навчатися в Німеччині на факультетах інформатики, математики, економіки та юриспруденції. Після успішного закінчення навчання видається диплом Фернуніверситету. Тим, хто не закінчив ВНЗ, пропонується вивчати окремі дисципліни з одержанням сертифіката [5, с. 45].

У Проблемній лабораторії дистанційного навчання Національного технічного університету «Харківський політехнічний інститут» до послуг слухачів «Основи педагогіки», «Веб-дизайн», «Практикум тьютора», «Основи інформаційних технологій і програмування». $€$ також дистанційні курси викладачів України (English for Technical Students та Управління персоналом), якими можна скористатися за символічну плату. Дистанційні курси розраховані, в основному, на підвищення кваліфікації [5, с. 46].

Отже, сучасна освіта в Україні безупинно розширює своє сприйняття комплексності світу та формування інформаційного суспільства, що виявляється в розширенні кола освітніх послуг для дорослих, використанні сучасних форм і методів навчання, включаючи дистанційну освіту.

\section{Література}

1. Десятов Т. М. Дистанційне навчання в системі неперервної освіти / Т. М. Десятов // Педагогіка і психологія. - 2003. - № 1. - С. 75 - 80. 2. Закон України «Про національну програму інформатизації» № 74/98- 
BP, із змінами № 2289-VI (2289-17) від 01.06.2010, ВBР, 2010. - Режим доступу: http: // zakon1.rada.gov.ua 3. Концепція розвитку дистанційної освіти в Україні // Затверджена Постановою МОН України В. Г. Кременем від 20 грудня 2000 р. - Режим доступу: http: // www.osvita.org.ua/distance/pravo/00.html 4. Олійник В. В. Дистанційне навчання в післядипломній педагогічній освіті: організаційно-науковий аспект / В. В. Олійник, В. О. Гравіт // Післядипломна освіта в Україні. - 2001. - № 1. - С. 39 - 44. 5. Післядипломна освіта: друга вища освіта, програми МВА, аспірантура, курси. 2005-2006: [довідник] / О. П. Голікова (уклад.), С. В. Шаповалов (уклад.). - К. : Хімджест, 2005. - 106 с. 